\title{
Daily seasonalities and stock market reforms in Spain
}

\author{
J. IGNACIO PEÑA \\ Departamento de Economía de la Empresa, Universidad Carlos III de Madrid, \\ C/Madrid 126-128, 28903 Getafe, Madrid, Spain
}

The effects of Spanish Stock Exchange Reform on the seasonal patterns of daily stock excess returns are addressed. Before the Reform, positive abnormal average Monday excess returns are found. Possible causes are discussed and related with clearing and trading mechanisms. After the Reform daily seasonal effects disappear, suggesting an increase in the market's operational efficiency.

\section{INTRODUCTION}

Research on weekend effects and other anomalies in financial markets has significantly expanded in recent years, as illustrated by Guimaraes et al. (1989). In particular, the day-of-the-week effect has been studied in a number of papers: French (1980), Gibbons and Hess (1981), Lakonishok and Levi (1982) and Lakonishok and Smidt (1987). Typically, all these studies used US stock market data. In these papers, Monday returns were found to be significantly negative while the returns on the last trading day of the week, Friday or Saturday, tended to be higher than for other days. International evidence on weekend effects are provided by Jaffe and Westerfield (1985), Condoyanni et al. (1987), Wong et al. (1992) and Peiró (1944). The evidence from these papers seems to suggest that foreign investors confront a day-of-the-week effect in their respective countries independent of the effect which exists in the US.

Explanations for the day-of-the-week effect have been proposed following two lines of argument. The first line of argument proposed that the weekend effect is mainly due to the different trading patterns of individual and institutional investors (Lakonishok and Maberly, 1990). The second line of argument maintains that day-of-the-week effects are related with country-specific settlement procedures, as explained in Solnik (1990). This paper presents evidence consistent with the latter line of argument, using data from the Spanish stock market.

Earlier analysis of possible day-of-the-week effects in the Spanish stock market found no evidence of daily seasonalities (Santesmases, 1986). His sample covered the period from 1979 to 1983 , with a trading period from Tuesday to 0960-3107 (C) 1995 Chapman \& Hall
Friday. Rubio (1991), using data from the period 1984 to 1988 , reports a positive and significant average Monday return. Martinez Abascal (1993) using data from the period 1985 to 1989 also found a positive Monday effect. Those results are in contrast with the documented weekend effect in the US market, where the average return on Friday is abnormally high and the average return on Monday is abnormally low.

This paper aims to extend the above mentioned Spanish stock market research using a larger sample period, from 1986 to 1993, and a more comprehensive database. The database includes the market's General Index and 60 individual common stocks grouped in seven sector-specific portfolios.

We found the positive Monday effect exists and we offer a possible explanation based on the clearing and trading procedures of the Spanish stock market. Another contribution of this paper is to take into account the effect of institutional changes in the market after the Spanish 'Big Bang', when the new Spanish Securities Market Act of 28th July 1988 began to operate on 29 July 1989.

The paper is organized as follows. First, the Spanish stock market structure is discussed. Then we present data, methodology and results. Clearing and trading procedures are addressed. The paper finalizes with the conclusions.

\section{MARKET STRUCTURE}

There are four stock markets in Spain; Madrid, Barcelona, Valencia and Bilbao. Madrid is the main exchange, accounting for almost $90 \%$ of trading activity. At the end of 1992 Madrid Stock Market's market value was about 1\% of 
total world market value. The largest individual sector in terms of market value was Banking ( $24 \%$ of the total), followed by Electrical Utilities $(21 \%)$. Telecommunications $(11 \%)$, Oil and Chemicals $(10 \%)$, Construction $(8 \%)$, Investments $(6 \%)$ and Metal Industry $(5 \%)$. Foreign investors are fully allowed to invest in the Spanish securities markets. The Spanish Securities Market Act (SSMA) took effect in July 1989 and its main points were:

(i) Official Stock Market Agents, previously appointed by the Government, were replaced by private brokers and dealers.

(ii) Introduction of the Computer Assisted Trading System (CATS) open from 11:00 am to 5:00 pm and the elimination of the traditional open outcry trading process. The CATS became fully operational in the first quarter of 1990 . However, some floor trading remains for small stocks, limited from 10:00 am to $12: 15 \mathrm{pm}$.

(iii) Previously regulated brokerage fees were liberalized, and the resulting commission price war among Spain's brokers has led commissions to come down to $0.12 \%$ or less for typical market transactions.

(iv) Institution of the National Stock Exchange Commission (CNMV), Spain's version of the US SEC.

(v) A new settlement and clearing service was created (NSL) and became operational at the same moment as the CATS. Cash balances are presently cleared in 48 hours. Before the introduction of the NSL, cash balances were cleared on Friday the week after operations. Moreover, the settlement reduced by 20 days after the introduction of the NSL, from 30 to 10 days after the transaction. In April 1993 the CNMV initiated its new Servicio de Compensacion y Liquidacion (SCVL), an improved securities settlement and clearing service aimed at further reducing to five days the settlement period.

\section{DATA AND METHODOLOGY}

The basic data set consists of daily returns of IGBM $^{1}$ and daily returns of a sample of 60 common stocks grouped in seven sectorial value-weighted portfolios: Banks (BAN), Electric Utilities (ELE), Communications (COM), Chemical and Oil (CHE), Construction (BUI), Investments (INV) and Metal Industrial (MET). The stocks in the sample are the most actively traded ones on the market and have been listed without interruption in the full sample period. Daily data for the 8-year period from 2 January 1986 to 31 March 1993 was used in this study (1885 data points).
The market value of these 60 stocks accounts for almost $80 \%$ of the total value on the Madrid Stock Market during this period. ${ }^{2}$

For each day, we computed the return as the percentage change in the value of the index (portfolio) from the previous day, taking into account dividends and stock splits. Then we substract the risk-free ${ }^{3}$ interest rate, to compute excess returns.

With respect to Mondays we additionally subtract the two-day rate to take account of the weekend devoid of interest. To take into account the introduction of the CATS we analysed the total sample and two subsets. As the new system was initiated at the end of 1989 and became fully operational in the first quarter of 1990 , we selected the last day of this period, 31 March 1990, as the effective date of the CATS implementation. We did not use the data from December 1989 to March 1990 to avoid problems with the transition period.

Following French (1980), Gibbons and Hess (1981) and Keim and Stambaugh (1984), we construct a test for differences in the mean return across the days of the week by computing the following regression for IGBM and the sectorial portfolios:

$$
r_{t(i)}=\alpha_{1} d_{1 t(i)}+\alpha_{2} d_{2 t(i)}+\cdots+\alpha_{5} d_{5 t(i)}+e_{t(i)}
$$

where $i=1,2,3$ and $t(1)=1, \ldots, 1885 ; t(2)=1, \ldots, 1000$; $t(3)=1101, \ldots, 1885$ and where $d_{1 t}=1$ if day $t$ is a Monday, and $d_{1 t}=0$ otherwise; $d_{2 t}=1$ if $t$ is a Tuesday, etc. Some preliminary data analysis pointed out non-constant variance and one-lag autocorrelation in the data. Therefore, to improve consistency and efficiency, we estimate model 1 allowing for first-order autocorrelation and heteroscedasticity:

$$
e_{t(i)}=\Phi_{1} r_{t-1(i)}+a_{t(i)} \quad a_{t(i)} \sim\left\langle 0, \sigma_{a_{t(i)}}^{2}\right\rangle
$$

For consistent inference based on estimated parameters in models 1 and 2, we use White's (1980) estimator of the parameters' covariance matrix.

The regressions were also run in an amended form with four dummy variables plus an intercept term. Arbitrarily a dummy variable for Mondays is excluded. The coefficients of this model are the means for each day of the week deviated from Monday. The $F$-statistics from these regressions ( $F 2$ in the tables) enable us to test if the observed excess return on Monday is different from the rest of the week. We performed the test for the full sample, before and after the CATS.

${ }^{1}$ The Madrid Stock Market general Index (IGBM) is made up each year of 70-90 firms and represents about 80-85\% of the total market value, excluding foreign stock. It accounts for dividends and stock splits, and is a market value weighted index. Therefore it is considered to reflect mainly the behaviour of the large firms.

${ }^{2}$ Details on the data (firms, sectors, etc.) are available on request.

${ }^{3}$ The risk-free rate is the daily return of a 90-day Spanish Government Bill. 
Table 1. Test for the day-of-the-week effect: full sample (1986-1993)

\begin{tabular}{|c|c|c|c|c|c|c|c|c|c|}
\hline Variable & Monday & Tuesday & Wednesday & Thursday & Friday & $F 1$ & $F 2$ & $Q(5)$ & $\Phi_{1}$ \\
\hline $\begin{array}{l}\text { IGBM } \\
t \text {-statistic }\end{array}$ & $\begin{array}{l}0.0013 \\
2.3^{\mathrm{b}}\end{array}$ & $\begin{array}{l}-0.0009 \\
-1.07\end{array}$ & $\begin{array}{l}-0.0003 \\
-1.17\end{array}$ & $\begin{array}{l}0.0004 \\
0.38\end{array}$ & $\begin{array}{l}0.0009 \\
1.68\end{array}$ & $30.06^{\mathrm{a}}$ & $3.1^{\mathrm{b}}$ & 4.91 & $\begin{array}{l}0.263 \\
5.2^{\mathrm{a}}\end{array}$ \\
\hline $\begin{array}{l}\text { BAN } \\
t \text {-statistic }\end{array}$ & $\begin{array}{l}0.0008 \\
1.3\end{array}$ & $\begin{array}{l}-0.0001 \\
-0.31\end{array}$ & $\begin{array}{l}-0.0007 \\
-1.6\end{array}$ & $\begin{array}{l}0.0003 \\
0.58\end{array}$ & $\begin{array}{l}0.0012 \\
2.1^{\mathrm{b}}\end{array}$ & $60.5^{\mathrm{a}}$ & 1.9 & 1.46 & $\begin{array}{l}0.365 \\
7.7^{\mathrm{a}}\end{array}$ \\
\hline $\begin{array}{l}\text { COM } \\
t \text {-statistic }\end{array}$ & $\begin{array}{l}0.0004 \\
0.4\end{array}$ & $\begin{array}{l}-0.0006 \\
-0.7\end{array}$ & $\begin{array}{l}-0.0002 \\
-0.2\end{array}$ & $\begin{array}{l}0.0012 \\
1.4\end{array}$ & $\begin{array}{l}0.0010 \\
1.0\end{array}$ & 1.86 & 1.7 & 2.2 & $\begin{array}{l}0.057 \\
0.097\end{array}$ \\
\hline $\begin{array}{l}\text { ELE } \\
t \text {-statistic }\end{array}$ & $\begin{array}{l}0.0026 \\
2.6^{\mathrm{a}}\end{array}$ & $\begin{array}{l}-0.0011 \\
-1.3\end{array}$ & $\begin{array}{l}-0.0005 \\
-0.6\end{array}$ & $\begin{array}{l}0.0000 \\
0.00\end{array}$ & $\begin{array}{l}0.0009 \\
1.04\end{array}$ & $9.17^{\mathrm{a}}$ & $3.1^{\mathrm{b}}$ & 2.8 & $\begin{array}{l}0.134 \\
2.6^{\mathrm{a}}\end{array}$ \\
\hline $\begin{array}{l}\text { MET } \\
t \text {-statistic }\end{array}$ & $\begin{array}{l}0.0036 \\
3.7^{\mathrm{a}}\end{array}$ & $\begin{array}{l}-0.0019 \\
-2.1^{\mathrm{b}}\end{array}$ & $\begin{array}{l}-0.011 \\
-1.35\end{array}$ & $\begin{array}{l}0.0005 \\
0.60\end{array}$ & $\begin{array}{l}-0.0011 \\
-1.4\end{array}$ & $140.1^{a}$ & $6.4^{a}$ & 1.2 & $\begin{array}{l}0.179 \\
3.5^{\mathrm{a}}\end{array}$ \\
\hline $\begin{array}{l}\text { CHE } \\
t \text {-statistic }\end{array}$ & $\begin{array}{l}0.0034 \\
3.6^{\mathrm{a}}\end{array}$ & $\begin{array}{l}-0.0021 \\
-1.9\end{array}$ & $\begin{array}{l}0.0004 \\
0.53\end{array}$ & $\begin{array}{l}-0.0000 \\
-0.7\end{array}$ & $\begin{array}{l}-0.0003 \\
-0.42\end{array}$ & $34.17^{\mathrm{a}}$ & $5.2^{\mathrm{a}}$ & 1.48 & $\begin{array}{l}0.184 \\
4.9^{\mathrm{a}}\end{array}$ \\
\hline $\begin{array}{l}\text { BUI } \\
t \text {-statistic }\end{array}$ & $\begin{array}{l}0.0028 \\
2.6^{\mathrm{a}}\end{array}$ & $\begin{array}{l}-0.0016 \\
-1.8\end{array}$ & $\begin{array}{l}-0.0006 \\
-0.8\end{array}$ & $\begin{array}{l}0.0008 \\
1.1\end{array}$ & $\begin{array}{l}0.0007 \\
1.0\end{array}$ & $48.9^{\mathrm{a}}$ & $3.2^{\mathrm{b}}$ & 1.6 & $\begin{array}{l}0.305 \\
8.9^{\mathrm{a}}\end{array}$ \\
\hline $\begin{array}{l}\text { INV } \\
t \text {-statistic }\end{array}$ & $\begin{array}{l}0.0007 \\
1.1\end{array}$ & $\begin{array}{l}-0.0006 \\
-0.8\end{array}$ & $\begin{array}{l}-0.0001 \\
-0.2\end{array}$ & $\begin{array}{l}0.0002 \\
0.3\end{array}$ & $\begin{array}{l}0.0010 \\
1.5\end{array}$ & $25.6^{a}$ & 1.1 & 4.3 & $\begin{array}{l}0.311 \\
7.2^{\mathrm{a}}\end{array}$ \\
\hline
\end{tabular}

${ }^{\mathrm{a}} 1 \%$ significant; ${ }^{\mathrm{b}} 5 \%$ significant

The $t$-statistic is testing the hypothesis that the mean excess return on the particular day is zero. The $F 1$ statistic is testing the hypothesis that the mean excess return across all days of the week is the same and equal to zero. The $F 2$ statistic is testing the hypothesis that the mean excess return on Mondays is equal to the average across the other four trading days of the week. The $Q(5)$ statistic is the Ljung-Box portmanteau and is testing if the first five residual autocorrelations are jointly zero. The parameter $\Phi$ is the first-order autoregressive coefficient in Equation 2.

\section{Empirical results}

Results are reported in Tables 1 to 3 . $t$-Statistics suggest a significant positive average Monday return both for IGBM and the sectorial portfolios. The day-of-the-week effect is significant in the full sample (Table 1), and even stronger before the CATS (Table 2). However, the effect becomes negligible after the CATS (Table 3). Note also the values of $F 2$ statistics, which test whether the observed excess returns on Mondays is different from the rest of the week. In the full sample and before the CATS, we can reject the equality hypothesis at reasonable significance levels. After the CATS, however, the hypothesis is not rejected. ${ }^{4}$

Highly significant $\Phi_{1}$ parameters can be related to nonsynchronous trading problems and associated factors addressed elsewhere (see Peña (1995) for evidence on these issues). This result does not necessarily imply evidence against the weak form of market efficiency. Before the CATS, autocorrelation seems to be more significant, especially in the Banks portfolio. One reason for this might be that, before the CATS, Banks were not traded in the usual open outcry market, but instead followed a written order entry system ('par cassiers'). The method is that trading orders are accumulated in an order 'book' and, using a computer program, one clearing price is provided. Spanish banks used to care about their own price quotations and usually some kind of intervention (either direct or through other participated firms) was not uncommon. Evidence on this practice and other specific features of the banking sector in the Spanish stock market are presented in Berges and Soria (1992).

The consequences of our results for the weak form of the Efficient Market hypothesis could be addressed designing trading systems to take into account those regularities and, adjusting for market risk and brokerage fees, compare its profits against a conservative buy-and-hold policy. For instance we could buy a selected portfolio on Tuesdays or Wednesdays and sell on Mondays. Some simple simulation exercises were performed (available on request) and the results confirm simulations reported in Martinez Abascal (1993). The transaction costs are high and only a small economically significant profit (before taxes) can be obtained.

After the CATS, no weekday effects are apparent and the autocorrelations are lower, suggesting improvements in the market's operational efficiency.

\footnotetext{
${ }^{4}$ The stock market crash of 1987 occurred in the full sample period and in the before the CATS period. To check the possible influence of this event on the results, we estimated models 1 and 2 for all series in the full sample and before the CATS, deleting the data for October 1987. In both cases, there are slight increases in the estimators of the Monday dummy variable and in the significance of $F 1$ and $F 2$ statistics. However, these increases are barely significant. Therefore we may say that our results are not affected in a significant way by the 1987 events.
} 
Table 2. Test for the day-of-the-week effect: before the CATS (1986-1989)

\begin{tabular}{|c|c|c|c|c|c|c|c|c|c|}
\hline Variable & Monday & Tuesday & Wednesday & Thursday & Friday & $F 1$ & $F 2$ & $Q(5)$ & $\Phi_{1}$ \\
\hline $\begin{array}{l}\text { IGBM } \\
t \text {-statistic }\end{array}$ & $\begin{array}{l}0.0033 \\
4.3^{\mathrm{a}}\end{array}$ & $\begin{array}{l}-0.0014 \\
-1.9\end{array}$ & $\begin{array}{l}0.0000 \\
0.00\end{array}$ & $\begin{array}{l}0.0006 \\
0.83\end{array}$ & $\begin{array}{l}0.0008 \\
1.06\end{array}$ & $39.26^{\mathrm{a}}$ & $5.7^{\mathrm{a}}$ & 9.1 & $\begin{array}{l}0.367 \\
5.3^{\mathrm{a}}\end{array}$ \\
\hline $\begin{array}{l}\text { BAN } \\
t \text {-statistic }\end{array}$ & $\begin{array}{l}0.0019 \\
3.3^{\mathrm{a}}\end{array}$ & $\begin{array}{l}-0.0007 \\
-1.0\end{array}$ & $\begin{array}{l}-0.0003 \\
-0.6\end{array}$ & $\begin{array}{l}0.0002 \\
0.48\end{array}$ & $\begin{array}{l}0.0018 \\
3.1^{\mathrm{a}}\end{array}$ & $112.4^{\mathrm{a}}$ & $4.5^{\mathrm{a}}$ & 4.1 & $\begin{array}{l}0.574 \\
11^{\mathrm{a}}\end{array}$ \\
\hline $\begin{array}{l}\mathrm{COM} \\
t \text {-statistic }\end{array}$ & $\begin{array}{l}0.0012 \\
0.8\end{array}$ & $\begin{array}{l}-0.0022 \\
-1.5\end{array}$ & $\begin{array}{l}-0.0002 \\
-0.2\end{array}$ & $\begin{array}{l}0.0012 \\
1.0\end{array}$ & $\begin{array}{l}0.0013 \\
0.88\end{array}$ & 1.96 & 1.8 & 4.3 & $\begin{array}{l}0.065 \\
0.087\end{array}$ \\
\hline $\begin{array}{l}\text { ELE } \\
t \text {-statistic }\end{array}$ & $\begin{array}{l}0.0049 \\
3.6^{\mathrm{a}}\end{array}$ & $\begin{array}{l}-0.0011 \\
-1.3\end{array}$ & $\begin{array}{l}-0.0004 \\
-0.4\end{array}$ & $\begin{array}{c}-0.0002 \\
0.23\end{array}$ & $\begin{array}{l}0.0006 \\
0.4\end{array}$ & $9.12^{\mathrm{a}}$ & $4.6^{\mathrm{a}}$ & 7.5 & $\begin{array}{l}0.155 \\
2.5^{\mathrm{a}}\end{array}$ \\
\hline $\begin{array}{l}\text { MET } \\
t \text {-statistic }\end{array}$ & $\begin{array}{l}0.0087 \\
5.8^{\mathrm{a}}\end{array}$ & $\begin{array}{l}-0.0013 \\
-1.3\end{array}$ & $\begin{array}{l}-0.0022 \\
-1.75\end{array}$ & $\begin{array}{l}0.0016 \\
1.3\end{array}$ & $\begin{array}{c}-0.0010 \\
0.84\end{array}$ & $111.1^{\mathrm{a}}$ & $7.2^{\mathrm{a}}$ & 10.2 & $\begin{array}{l}0.171 \\
3.3^{\mathrm{a}}\end{array}$ \\
\hline $\begin{array}{l}\text { CHE } \\
t \text {-statistic }\end{array}$ & $\begin{array}{l}0.0068 \\
5.3^{\mathrm{a}}\end{array}$ & $\begin{array}{l}-0.0015 \\
-1.5\end{array}$ & $\begin{array}{l}0.0010 \\
0.93\end{array}$ & $\begin{array}{l}0.0002 \\
0.27\end{array}$ & $\begin{array}{c}-0.0008 \\
0.78\end{array}$ & $32.4^{\mathrm{a}}$ & $6.9^{\mathrm{a}}$ & 5.2 & $\begin{array}{l}0.264 \\
6.3^{\mathrm{a}}\end{array}$ \\
\hline $\begin{array}{l}\text { BUI } \\
t \text {-statistic }\end{array}$ & $\begin{array}{l}0.0057 \\
5.5^{\mathrm{a}}\end{array}$ & $\begin{array}{l}-0.0023 \\
-2.01^{b}\end{array}$ & $\begin{array}{l}-0.0001 \\
-1.6\end{array}$ & $\begin{array}{l}0.0015 \\
1.9\end{array}$ & $\begin{array}{l}0.0007 \\
0.70\end{array}$ & $51.4^{a}$ & $6.8^{\mathrm{a}}$ & 4.8 & $\begin{array}{l}0.361 \\
7.7^{\mathrm{a}}\end{array}$ \\
\hline $\begin{array}{l}\text { INV } \\
t \text {-statistic }\end{array}$ & $\begin{array}{l}0.0017 \\
2.2^{\mathrm{b}}\end{array}$ & $\begin{array}{l}-0.0012 \\
-1.6\end{array}$ & $\begin{array}{l}-0.0008 \\
-0.2\end{array}$ & $\begin{array}{l}0.0013 \\
1.9\end{array}$ & $\begin{array}{l}0.0011 \\
1.4\end{array}$ & $28.6^{\mathrm{a}}$ & $4.3^{\mathrm{a}}$ & 4.5 & $\begin{array}{l}0.212 \\
6.1^{\mathrm{a}}\end{array}$ \\
\hline
\end{tabular}

${ }^{\mathrm{a}} 1 \%$ significant; ${ }^{\mathrm{b}} 5 \%$ significant

The $t$-statistic is testing the hypothesis that the mean excess return on the particular day is zero. The $F 1$ statistic is testing the hypothesis that the mean excess return across all days of the week is the same and equal to zero. The $F 2$ statistic is testing the hypothesis that the mean excess return on Mondays is equal to the average across the other four trading days of the week. The $Q(5)$ statistic is the Ljung-Box portmanteau and is testing if the first five residual autocorrelations are jointly zero. The parameter $\Phi$ is the first-order autoregressive coefficient in Equation 2.

Table 3. Test for the day-of-the-week effect: after the CATS (1990-1993)

\begin{tabular}{|c|c|c|c|c|c|c|c|c|c|}
\hline Variable & Monday & Tuesday & Wednesday & Thursday & Friday & $F 1$ & $F 2$ & $Q(5)$ & $\Phi_{1}$ \\
\hline $\begin{array}{l}\text { IGBM } \\
t \text {-statistic }\end{array}$ & $\begin{array}{l}-0.0009 \\
-0.8\end{array}$ & $\begin{array}{l}0.0010 \\
1.1\end{array}$ & $\begin{array}{l}-0.0011 \\
-1.6\end{array}$ & $\begin{array}{l}-0.0004 \\
-0.47\end{array}$ & $\begin{array}{l}0.0009 \\
1.08\end{array}$ & 1.51 & 0.85 & 1.46 & $\begin{array}{l}0.124 \\
1.9\end{array}$ \\
\hline $\begin{array}{l}\text { BAN } \\
t \text {-statistic }\end{array}$ & $\begin{array}{l}-0.0011 \\
-0.9\end{array}$ & $\begin{array}{l}0.0008 \\
0.92\end{array}$ & $\begin{array}{l}-0.0013 \\
-1.56\end{array}$ & $\begin{array}{l}0.0002 \\
0.23\end{array}$ & $\begin{array}{l}0.0012 \\
1.3\end{array}$ & 1.77 & 1.81 & 2.3 & $\begin{array}{l}0.169 \\
2.6^{\mathrm{a}}\end{array}$ \\
\hline $\begin{array}{l}\mathrm{COM} \\
t \text {-statistic }\end{array}$ & $\begin{array}{l}-0.0007 \\
-0.6\end{array}$ & $\begin{array}{l}0.015 \\
1.7\end{array}$ & $\begin{array}{l}-0.0001 \\
-0.12\end{array}$ & $\begin{array}{l}0.0012 \\
1.2\end{array}$ & $\begin{array}{l}0.0006 \\
0.5\end{array}$ & 0.86 & 0.07 & 1.1 & $\begin{array}{l}0.034 \\
0.65\end{array}$ \\
\hline $\begin{array}{l}\text { ELE } \\
t \text {-statistic }\end{array}$ & $\begin{array}{l}-0.0006 \\
-0.5\end{array}$ & $\begin{array}{l}0.0014 \\
1.6\end{array}$ & $\begin{array}{l}-0.0004 \\
-0.6\end{array}$ & $\begin{array}{l}0.0005 \\
0.58\end{array}$ & $\begin{array}{l}0.0013 \\
1.48\end{array}$ & 1.19 & 1.01 & 2.2 & $\begin{array}{l}0.087 \\
1.2\end{array}$ \\
\hline $\begin{array}{l}\text { MET } \\
t \text {-statistic }\end{array}$ & $\begin{array}{l}0.0019 \\
1.8\end{array}$ & $\begin{array}{l}-0.0012 \\
-1.1\end{array}$ & $\begin{array}{l}-0.0018 \\
-1.6\end{array}$ & $\begin{array}{l}-0.0017 \\
-1.6\end{array}$ & $\begin{array}{l}-0.0013 \\
-1.2\end{array}$ & $3.9^{\mathbf{b}}$ & 1.2 & 1.5 & $\begin{array}{l}0.157 \\
2.5^{\mathrm{a}}\end{array}$ \\
\hline $\begin{array}{l}\text { CHE } \\
t \text {-statistic }\end{array}$ & $\begin{array}{l}0.0006 \\
0.6\end{array}$ & $\begin{array}{l}0.0003 \\
0.24\end{array}$ & $\begin{array}{l}-0.0000 \\
-0.06\end{array}$ & $\begin{array}{l}-0.0005 \\
-0.57\end{array}$ & $\begin{array}{l}0.0003 \\
0.32\end{array}$ & 0.03 & 2.1 & 2.1 & $\begin{array}{l}0.028 \\
0.43\end{array}$ \\
\hline $\begin{array}{l}\text { BUI } \\
t \text {-statistic }\end{array}$ & $\begin{array}{l}0.0005 \\
0.4\end{array}$ & $\begin{array}{l}-0.0010 \\
-0.8\end{array}$ & $\begin{array}{l}-0.0015 \\
-1.2\end{array}$ & $\begin{aligned} & 0.0020 \\
- & 1.6\end{aligned}$ & $\begin{array}{l}-0.0000 \\
-0.02\end{array}$ & $2.65^{\mathrm{b}}$ & 0.67 & 2.8 & -0.218 \\
\hline $\begin{array}{l}\text { INV } \\
t \text {-statistic }\end{array}$ & $\begin{array}{l}-0.0014 \\
-1.1\end{array}$ & $\begin{array}{l}-0.0012 \\
-0.9\end{array}$ & $\begin{array}{l}-0.0015 \\
-1.2\end{array}$ & $\begin{array}{l}-0.0025 \\
-2.0^{\mathbf{b}}\end{array}$ & $\begin{array}{l}0.0011 \\
0.95\end{array}$ & $5.1^{\mathrm{a}}$ & 1.4 & 1.6 & $\begin{array}{l}0.087 \\
2.3^{\mathbf{b}}\end{array}$ \\
\hline
\end{tabular}

${ }^{\mathrm{a}} 1 \%$ significant; ${ }^{\mathrm{b}} 5 \%$ significant

The $t$-statistic is testing the hypothesis that the mean excess return on the particular day is zero. The $F 1$ statistic is testing the hypothesis that the mean excess return across all days of the week is the same and equal to zero. The $F 2$ statistic is testing the hypothesis that the mean excess return on Mondays is equal to the average across the other four trading days of the week. The $Q(5)$ statistic is the Ljung-Box portmanteau and is testing if the first five residual autocorrelations are jointly zero. The parameter $\Phi$ is the first-order autoregressive coefficient in Equation 2.

\section{A comment on trading and clearing procedures}

It may be argued that before the CATS, trading and clearing effects might explain, at least, part of the day-of-the-week effect. In fact, it was not unusual for some official market agents to accumulate orders coming from outside Madrid near the end of one given week (Thursday and Friday) and process them at the beginning (Monday) of the next week. This might cause some price pressures at the beginning of the week. 
Another explanation could relate to clearing mechanisms as follows. Before the CATS, any transaction (buy/sell) in one given week (from Monday to Friday) was cleared in cash on the Friday of the next week. This gives the investor the opportunity of buying stocks without using any cash, provided that offsetting orders are placed before the end of the week. Therefore, an extra volume of buy orders should be expected on Monday to profit from five-day trading without cash. Unfortunately, data on sell and buy orders are not available for daily samples.

\section{CONCLUSIONS}

The existence of a peculiar form of the weekend effect is studied in the Spanish stock market. In the period from 1986 to 1989, average Monday excess returns were positive and abnormally high. Also, high autocorrelations are found suggesting significant trading frictions in this market, especially in the banks sector. However it is not clear whether trading systems based on these empirical regularities could 'beat the market'.

Our results suggest that the Big Bang, i.e the introduction of the new system of clearing and trading in 1990, has improved the operational efficiency of the Spanish stock market. Empirical evidence on decreases in trade frictions is presented and related with decreasing inertia in excess returns autocorrelations. Furthermore, after the introduction of the CATS we do not find significant day-of-the-week effects. In summary, this paper presents evidence consistent with the country-specific trading procedures explanation of the weekend effects.

\section{ACKNOWLEDGEMENTS}

The author thanks Hanno Roberts for helpful comments. The paper has also benefitted greatly from the suggestions of an anonymous referee. Financial support was provided by DGICYT grant PB93-0234.

\section{REFERENCES}

Berges, A. and Soria, P. (1992) Comportamiento Bursatil de los Bancos Españoles, Civitas-Escuela de Economia.

Condoyanni, L., O'Hanlon, J. and Ward, C. W. R. (1987) Day of the week effects on stock returns: international evidence, Journal of Business Finance and Accounting, 14, 159-74.

French, K. (1980) Stock returns and the weekend effect, Journal of Financial Econimics, 8, 55-70.

Gibbons, M. R. and Hess, P. (1981) Day of the week effects and asset returns, Journal of Business, 54, 579-96.

Guimaraes, R. M. C., Kingsman, B. G. and Taylor, S. J. (eds) (1989) A Reapparaisal of the Efficiency of Financial Markets, NATO ASI Series, Springer-Verlag, Berlin.

Jaffe, J. and Westerfield, R. (1985) The week-end effect in common stock returns: the international evidence, Journal of Finance, 40, 433-54.

Keim, D. and Stambaugh, R. (1984) A further investigation of the weekend in stock returns, Journal of Finance, 39, 819-34.

Lakonishok, J. and Levi, M. (1982) Weekend effects on stock returns: a note, Journal of Finance, 37, 883-889.

Lakonishok, J. and Maberly, E. (1990) The weekend effect: trading patterns of individual and institutional investors, Journal of Finance, 45, 231-243.

Lakonishok, J. and Smidt, S. (1987) Are seasonal anomalies real? A ninety year perspective. Working Paper. Cornell University.

Martinez Abascal, E. (1993) Eficiencia Debil del Mercado Bursatil Español y Comparaciones Internacionales, Bolsa de Madrid.

Peiró, A. (1994) Daily seasonality in stock returns. Further international evidence, Economics Letters, 45, 227-232.

Peña, J. I. (1995) Nonsynchronous trading, efficiency and market reforms. International Journal of Management (forthcoming).

Rubio, G. (1991) The stock market in Spain: performance, structure and the behavior of asset prices, Journal of Financial Markets and Portfolio Management, 3, 45-92.

Santesmases, M. (1986) An investigation of the Spanish stock market seasonalities, Journal of Business Finance and Accounting, 13, 267-76.

Solnik, B. (1990) The distribution of daily stock returns and settlement procedures: the paris Bourse, Journal of Finance, 45, 1601-09.

White, H. (1980) A heteroskedasticiy-consistent covariance matrix estimator and a direct test for heteroskedasticity, Econometrica, 48, 817-38.

Wong, K. A., Hui, T. K. and Chan, C. Y. (1992) Day-of-the-week effects: evidence from developing stock markets, Applied $\mathrm{Fi}$ nancial Economics, 2, 49-56. 